\title{
Strong genetic differentiation in tropical seagrass Enhalus acoroides (Hydrocharitaceae) at the Indo-Malay Archipelago revealed by microsatellite DNA
}

\author{
I Nyoman Giri Putra ${ }^{1,2}$, Yuliana Fitri Syamsuni ${ }^{3}$, Beginer Subhan ${ }^{1}$, Made Pharmawati ${ }^{4}$, Hawis Madduppa \\ Corresp. 1,5 \\ 1 Department of Marine Science and Technology, Faculty Fisheries and Marine Sciences, Bogor Agricultural University (IPB), Bogor, Indonesia \\ Department of Marine Science, Faculty of Marine Science and Fisheries,, Udayana University, Denpasar, Indonesia \\ 3 Indonesian Biodiversity Research Center, Denpasar, Indonesia \\ 4 Biology Department, Faculty of Mathematics and Natural Sciences, Udayana University, Denpasar, Bali, Indonesia \\ ${ }^{5}$ Center for Coastal and Marine Resource Studies, Bogor Agricultural University (IPB), Bogor, Indonesia \\ Corresponding Author: Hawis Madduppa \\ Email address: hawis@apps.ipb.ac.id
}

The Indo-Malay Archipelago is regarded as a barrier that separates organisms of the Indian and Pacific Oceans. Previous studies of marine biota from this region have found a variety of biogeographic barriers, seemingly dependent on taxon and methodology. Several hypotheses, such as emergence of the Sunda Shelf and recent physical oceanography, have been proposed to account for the genetic structuring of marine organisms in this region. Here, we used six microsatellite loci to infer genetic diversity, population differentiation and phylogeographic patterns of Enhalus acoroides across the Indo-Malay Archipelago. Heterozygosities were consistently high, and significant isolation-by-distance, consistent with restricted gene flow, was observed. Both a neighbour joining tree based on $D_{\mathrm{A}}$ distance and Bayesian clustering revealed three major clusters of $E$. acoroides. Our results indicate that phylogeographic patterns of $E$. acoroides have possibly been influenced by glaciation and deglaciation during the Pleistocene. Recent physical oceanography such as the South Java Current and the Seasonally Reversing Current may also play a role in shaping the genetic patterns of $E$. acoroides. 
1 Strong genetic differentiation in tropical seagrass Enhalus acoroides (Hydrocharitaceae) at

2 the Indo-Malay Archipelago revealed by microsatellite DNA

3

4 I Nyoman Giri Putra ${ }^{1,2}$, Yuliana Fitri Syamsuni ${ }^{3}$, Beginer Subhan ${ }^{1}$, Made Pharmawati ${ }^{4}$, Hawis

5 Madduppa ${ }^{1,5^{*}}$

6

$7{ }^{1}$ Department of Marine Science and Technology, Faculty Fisheries and Marine Sciences,

8 Bogor Agricultural University (IPB), Bogor, Indonesia

9 2Department of Marine Science, Faculty of Marine Science and Fisheries, Udayana University,

10 Badung, Bali, Indonesia

$11{ }^{3}$ Indonesian Biodiversity Research Center, Denpasar, Indonesia

$12{ }^{4}$ Biology Department, Faculty of Mathematics and Natural Sciences, Udayana University,

13 Badung, Bali, Indonesia

$14{ }^{5}$ Center for Coastal and Marine Resource Studies, Bogor Agricultural University (IPB), Jl. Raya

15 Pajajaran No.1, Kampus IPB Baranangsiang, Bogor 16217, Indonesia;

18 * Corresponding author:

19 E-mail address: hawis@apps.ipb.ac.id

20 Phone/Fax: +622518623644 


\section{Abstract}

24 The Indo-Malay Archipelago is regarded as a barrier that separates organisms of the Indian and

25 Pacific Oceans. Previous studies of marine biota from this region have found a variety of

26 biogeographic barriers, seemingly dependent on taxon and methodology. Several hypotheses,

27 such as emergence of the Sunda Shelf and recent physical oceanography, have been proposed to

28 account for the genetic structuring of marine organisms in this region. Here, we used six

29 microsatellite loci to infer genetic diversity, population differentiation and phylogeographic

30 patterns of Enhalus acoroides across the Indo-Malay Archipelago. Heterozygosities were

31 consistently high, and significant isolation-by-distance, consistent with restricted gene flow, was

32 observed. Both a neighbour joining tree based on $D_{\mathrm{A}}$ distance and Bayesian clustering revealed

33 three major clusters of E. acoroides. Our results indicate that phylogeographic patterns of $E$.

34 acoroides have possibly been influenced by glaciation and deglaciation during the Pleistocene.

35 Recent physical oceanography such as the South Java Current and the Seasonally Reversing

36 Current may also play a role in shaping the genetic patterns of E. acoroides. 


\section{Introduction}

The Indo-Malay Archipelago is one of the most important land barriers (The Indo-Pacific Barrier, IPB), separating the Indian and Pacific Oceans (Crandall et al., 2008). Although the location of the exact boundary is debated (Barber et al., 2006; DiBattista et al., 2012), many species show strong genetic differentiation between the Indian and Pacific populations, including marine plants, such as mangroves from the genus Ceriops (Huang et al., 2008) and the widely distributed Bruguiera gymnorrhiza (Urashi et al., 2013). Similar genetic differentiation between Indian and Pacific populations has also been demonstrated in diverse marine animals including reef fishes (Thresher and Brothers, 1985; Gaither et al. 2009), the marine gastropod, Nerita albicilla (Crandall et al., 2008), and the crown-of-thorns sea star Acanthaster planci (Vogler et al., 2008; Yasuda et al., 2009). Despite a growing number of such phylogeographic studies in the Indian and Pacific Ocean, only a few have tried to identify specific elements within the IndoMalay Archipelago responsible for establishing and maintaining these barriers (Carpenter et al., 2011; Keyse et al., 2014).

The Indo-Malay Archipelago consists mostly of large land masses such as Sumatra, ThaiMalay Peninsula, Borneo, and the Greater Sundas. During the last glacial maxima (LGM), these islands coalesced to form a large land mass known as the Sunda shelf (Voris, 2000). Despite their similar geological origin, the population structure of flora and fauna in these islands is not homogenous. Studies of the mantis shrimp Haptosquilla pulchella have revealed a sharp genetic break across the Java Sea, which divides the population into north (Pacific) and south (Indian) (Barber et al., 2002). Other studies on the giant clam Tridacna crocea (DeBoer et al., 2014) and frigate tuna Euthynnus affinis (Jackson et al., 2014), showed that the populations of Sumatra in western Indonesia resembles that of the Indian populations, while Java resembles central 
63 Indonesian populations. Meanwhile, studies of the mangrove Ceriops tagal (Liao, Havanond \&

64 Huang, 2006) and the seagrass Halophila ovalis (Nguyen et al., 2014), revealed a concordance in

65 the geographical barrier at the Thai Malay Peninsula, separating the Indian from the Pacific

66 populations. Thus, the phylogeographic patterns in these regions are quite complex.

67 Gene flow could be driven by various factors, such as currents (Barber et al., 2006) and the

68 geological history of a location (Hart \& Marko, 2010). Geographical history such as the

69 emergence of Sunda shelf during the Pleistocene period, is likely the main factor responsible for

70 historically limited gene flow between the Indian and Pacific Ocean, which then, may have

71 triggered lineage divergence in both oceans (Carpenter et al., 2011). In eastern Indonesia, the

72 Halmahera Eddy and Indonesian Throughflow are likely candidates shaping biogeographic

73 barriers between eastern and western Indonesia (Barber et al., 2006; Carpenter et al., 2011).

74 Other example, water circulation and an eddy located at the southern tip of Sumatra, plays a role

75 in maintaining the genetic structure of mangrove Rhizophora mucronata Lam. in the Malay

76 Peninsula and Sumatra (Wee et al., 2014).

77 Most phylogeographic studies across the Indo-Malay Archipelago to date have made use of

78 mitochondrial genes from marine animals, such as crustaceans (Barber, Erdmann \& Palumbi,

79 2006), reef fishes (Nelson et al., 2000; Ackiss et al., 2013), and bivalves (DeBoer et al., 2008).

80 These studies have found concordant phylogeographic breaks between populations in the Indian

81 Ocean and Java Sea. However, other marine animals, such as pelagic scads Decapterus

82 macrosoma (Arnaud-Haond, Bonhomme \& Borsa, 1999), and the marine gastropod Nerita

83 plicata (Crandall et al., 2008), show no evidence of genetic structuring among these same

84 regions. In contrast to the animals, study of marine plants, such as mangroves, with nuclear DNA

85 markers revealed a genetic discontinuity of mangrove Rhizophora mucronata, at the boundary 
86 between the Andaman Sea and Malacca Strait (Wee et al., 2014). Meanwhile, despite being an

87 important foundational species, phylogeographic studies examining genetic patterns in

88 seagrasses are currently lacking in this historically complex region.

89 Seagrasses are marine angiosperms that live in coastal areas on a substrate of sand, mud or 90 a mixture of both, and most of their life cycle occurs below sea level. Enhalus acoroides is one

91 seagrass species that is widely distributed in the Indo-Pacific from southern Japan, Southeast

92 Asia, northern Australia, southern India and Sri Lanka (Short \& Waycott, 2010). In Indonesia, E.

93 acoroides can be found in Papua, North Maluku, Ambon, Sulawesi, Bali, Java, Borneo, and

94 Sumatra (Kiswara \& Hutomo, 1985). This species can be easily distinguished from other

95 seagrasses because it has long leaves, the edges of the leaves are slightly rolled, and the rhizomes

96 are thick and covered with black fibrous strands (which are the remnants of old leaves). Fruits of

97 E. acoroides are capable of floating for up to 10.2 days (Lacap et al., 2002), during which they

98 could reach a distance of between $0.1-63.5 \mathrm{~km}$ (Lacap et al., 2002). This might limit the

99 dispersal of E. acoroides, although, occasional long distance dispersal $(>1,000 \mathrm{~km})$ of this

100 species is also possible due to strong currents (Nakajima et al., 2014). Species with limited

101 dispersal tendency are frequently hypothesized to be more genetically structured (Bay, Crozier \&

102 Caley, 2006) and thus, we expect to find significant population structure in this species.

103 Most seagrasses species are still categorized to be of least concern according to the IUCN

104 criteria, but many researchers have reported that seagrasses populations are in continual decline

105 around the globe (Waycott et al., 2009). Major loses of seagrass beds in Indonesia due to

106 anthropogenic disturbances (for example, mining, coastal development, and polluted runoff)

107 have been reported for decades, but restoration programs have only been initiated in the past few

108 years (Riani et al., 2012). Population size reduction is known to cause loss of genetic diversity 
109 (Allcock \& Strugnell, 2012) and a consequent elevated species extinction risk (Spielman, Brook

$110 \&$ Frankham, 2004). In order to adequately preserve and manage seagrass ecosystems, the

111 assessment of genetic diversity of seagrass species is essential.

112 Microsatellites are co-inherited and highly polymorphic markers (Selkoe \& Toonen, 2006)

113 and have been used broadly in population genetics and phylogeographic studies (Poortvliet et al.,

114 2013; Madduppa et al., 2014; Nakajima et al., 2014;Wee et al., 2014). In this study, six

115 previously developed microsatellite loci (Nakajima et al., 2012) were used to evaluate the

116 genetic diversity, population structure and phylogeographic patterns of E. acoroides and to infer

117 how the Sunda Shelf and regional currents shape the genetic patterns found in this species .

118

\section{2. Materials and methods}

$120 \quad 2.1$ Study area and sampling

121 A total of 202 E. acoroides samples from seven localities from Java and Sumatra were 122 collected in 2014 (Fig. 1, Table 1). At each location, 18-42 individuals were taken in a zigzag

123 pattern along a line transect. To avoid collection of the same genet or clone, only one shoot was

124 collected within a diameter of minimum of $5 \mathrm{~m}$ (pers. comm, Demian A. Willette, 2013).

125 Collected shoots were rinsed with fresh water to remove epiphytic algae. A young leaf from each

126 shoot was desiccated with silica gel and preserved at room temperature until use.

127

$128 \quad 2.2$ DNA extraction and amplification

129 Silica gel-dried leaves $(5 \mathrm{~cm}$ in length) from each shoot were ground using a mortar and

130 pestle. Genomic DNA was extracted using DNeasy plant mini kit (Qiagen $\left.{ }^{\circledR}\right)$ following the

131 manufacturer's protocol. Eight microsatellite loci (Eaco_001, Eaco_009, Eaco_019, Eaco_050, 
132 Eaco_051, Eaco_052, Eaco_054, Eaco_055) developed by Nakajima et al. (2012) were used to

133 score individual genotypes (Table 2). Forward primers were each labeled with a fluorescent dye

134 6-FAM, NED, PET or VIC (Applied Biosystems) (Table 2).

135 Polymerase Chain Reaction (PCR) was performed into two ways. (i) five loci (Eaco_001,

136 Eaco_009, Eaco_019, Eaco_051, Eaco_054) were amplified using the Qiagen multiplex PCR Kit

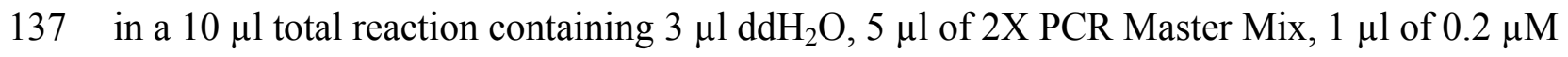

138 primer mix and $1 \mu 1$ template DNA. PCR cycling was carried out for $5 \mathrm{~min}$ at $95^{\circ} \mathrm{C}$, followed by

13935 cycles of $30 \mathrm{~s}$ at $95^{\circ} \mathrm{C}, 1.5 \mathrm{~min}$ at $57^{\circ} \mathrm{C}$ and $30 \mathrm{~s}$ at $72^{\circ} \mathrm{C}$ with an extension of 30 min at $60^{\circ} \mathrm{C}$

140 in the final cycle. (ii)three loci (Eaco_050, Eaco_052, Eaco_055) were amplified in a $20 \mu 1$ total

141 reaction containing $7.8 \mu \mathrm{lddH}_{2} \mathrm{O}, 2 \mu \mathrm{l}$ of $1 \mathrm{X}$ PCR gold buffer, $2 \mu \mathrm{MgCl}_{2}(2.5 \mathrm{mM}), 2 \mu 1 \mathrm{dNTPs}$

$142(200 \mu \mathrm{m}), 1.5 \mu \mathrm{l}$ of each $0.75 \mu \mathrm{m}$ primer, $1 \mathrm{U}$ taq polymerase (Applied Biosystem $\left.{ }^{\circledR}\right)$ and $3 \mu 1$

143 DNA template. PCR cycling was carried out for $15 \mathrm{~min}$ at $95^{\circ} \mathrm{C}$, followed by 32 cycles of $30 \mathrm{~s}$ at

$14494^{\circ} \mathrm{C}, 1.5 \mathrm{~min}$ at $58^{\circ} \mathrm{C}$ and $60 \mathrm{~s}$ at $72^{\circ} \mathrm{C}$ with an extension of $30 \mathrm{~min}$ at $60^{\circ} \mathrm{C}$ in the final cycle.

145 All PCRs were performed on a 2720 Thermal Cycler (Applied Biosystem ${ }^{\circledR}$ ). GeneScan ${ }^{\text {TM }} 500$

146 LIZ $^{\circledR}$ (Applied Biosystems ${ }^{\circledR}$ ) was used as an internal lane standard and PCR products were sent

147 to UC Berkeley DNA Sequencing Facility, USA, where they were run on an ABI 3130 X1

148 automated DNA sequencer (Applied Biosystem ${ }^{\circledR}$ ). Individual genotypes were scored using

149 Geneious ver. 7.0.6 (Kearse et al., 2012).

150

1512.3 Data analysis

152 2.3.1 Genetic diversity and Hardy-Weinberg equilibrium (HWE)

153 The number of alleles $(\mathrm{A})$, observed heterozygosities $\left(H_{\mathrm{O}}\right)$ and expected heterozygosities

$154\left(H_{\mathrm{E}}\right)$ were calculated using Genalex ver. 6.5 (Peakall \& Smouse, 2012). Departures from Hardy- 
155 Weinberg equilibrium (HWE) for each locus in all populations was computed via the Markov

156 Chain method (dememorization $=1,000$, batch $=100$, iterations per batch $=1,000)$ using

157 Genepop on the web (Jennings \& Blanchard, 2004). Levels of statistical significance were

158 corrected according to a false discovery rate (FDR) correction (Benjamini \& Hochberg, 1995).

159 Microchecker (Van Oosterhout et al., 2004) was used to check for existence of null alleles and

160 genotypic scoring error due to stuttering with 1,000 randomizations and a $95 \%$ confidence level.

161 Null allele frequencies were estimated for each locus and population by the expectation

162 maximization (EM) algorithm (Dempster, Laird \& Rubin, 1977) as implemented in FreeNA

163 (Chapuis \& Estoup, 2007).

164

165 2.3.2 Population structure

166 Genetic structure among populations was assessed in multiple ways. First, genetic

167 differentiation was estimated between pairs of populations with the estimator $\theta$ (Weir $\&$

168 Cockerham, 1984) as implemented in Arlequin ver. 3.5.1 (Excoffier \& Lischer, 2010). Second,

169 we inferred the phylogenetic relationship among populations using Poptree2 (Takezaki, Nei \&

170 Tamura, 2010) with the Neighbor Joining method (Saitou \& Nei, 1987) using Nei’s $\mathrm{D}_{\mathrm{A}}$ distance

171 (Nei, Tajima \& Tateno, 1983) and 1,000 bootstrapping replicates. Tree topology was rooted

172 using Mega 5 (Tamura et al., 2011).

173 Third, we used Structure 2.3.4 (Pritchard, Stephens \& Donnelly, 2000) to infer population

174 clustering and assign individuals to groups based on their microsatellite genotype. Five replicate

175 runs were conducted for each $\mathrm{K}$ between 1 and 10 using an admixture model and assuming

176 correlated allele frequencies (Falush, Stephens \& Pritchard, 2003). Each run consisted of a burn-

177 in of 20,000 followed by 100,000 steps of Markov Chain Monte Carlo (MCMC) sampling. The 
178 best $\mathrm{K}$ was determined using the $\Delta \mathrm{K}$ method (Evanno, Regnaut \& Goudet, 2005) as implemented

179 in Structure Harvester (Earl \& VonHoldt, 2012). Run data were merged by Clumpp (Jakobsson

$180 \&$ Rosenberg, 2007) and population structure then displayed graphically using Distruct

181 (Rosenberg, 2004).

182 Finally, we used a Mantel test to evaluate the statistical significance of isolation-by-distance

183 (IBD). To control for the potential existence of hierarchical population structure (Meirmans,

184 2012), we also estimated partial Mantel tests controlling for geographic distance and the

185 clustering groups previously identified, which best explained the genetic structure. Pairwise

186 genetic distances $\left(F_{\mathrm{ST}}\right)$ among localities were imported from Arlequin. A geographic distance

187 matrix was generated using the PATH tool implemented in Google Earth (Google Earth Plus for

188 Windows) that calculates the shortest distance by sea. In the third matrix used to run the partial

189 Mantel test, populations belonging to the same clustering group were coded with 0 , and

190 populations belonging to different clustering groups with 1. Both Mantel and partial mantel tests

191 were performed using Isolation-by-distance Web Service (IBDWS) version 3.23 (Jensen,

192 Bohonak \& Kelley, 2005) with 10,000 randomizations.

193

194

195 3. Results

1963.1 Genetic diversity and Hardy-Weinberg equilibrium

197 Two loci (Eaco_052 and Eaco_050) were discarded after initial examination because of

198 quality control issues. Eaco_052 had only a single allele in all populations (monomorphic), while

199 Eaco_050 was not successfully amplified in most samples. Thus, only six loci (Eaco_001,

200 Eaco_009, Eaco_019, Eaco_051, Eaco_054, and Eaco_055) were used for further analysis 
201 (Table 3). All samples were successfully amplified for all six loci, except a single sample from 202 ANS for which Eaco_051 could not be amplified.

203 A total of 89 alleles were detected across these six microsatellite loci, ranging from one 204 allele at the locus Eaco_019 in BM, KJ, BK, and ANS populations to 13 alleles at locus

205 Eaco_054 in the BM population. The mean number of alleles per locus ranged from 1.57 to 9.57, 206 and the mean number of alleles per population ranged from 4.33 to 7.00 (Table 2). The BM 207 population had the highest average number of alleles, while the lowest was found in the KJ 208 population. Observed heterozygosities ranged from 0.434 to 0.615 and expected $\left(H_{\mathrm{E}}\right)$ from 0.458 209 to 0.605 , respectively. The TD population had the highest $H_{\mathrm{E}}$ value (0.605), while the ANS 210 showed the lowest $H_{\mathrm{E}}(0.458)$.

211 Deviation from HWE is evidence that simple genetic models may not be appropriate 212 (Waples \& Allendorf, 2015). Hardy-Weinberg equilibrium tests revealed that five loci 213 (Eaco_001 in TD and NK, Eaco_009 in KJ and ANS, Eaco_051 in KJ, Eaco_054 in TD, NK, 214 ANS and Eaco_055 in ANS) deviated significantly from Hardy-Weinberg expectations $(\mathrm{P}<$ 215 0.05) prior to a multiple test correction with a false discovery rate. After correction for multiple 216 tests, only two loci significantly deviated from Hardy-Weinberg equilibrium (Eaco_001 and 217 Eaco_054).

218 Microchecker detected homozygote excess at locus Eaco_054 in TD and ANS and at locus 219 Eaco_001 in TD and NK, likely a result of null alleles. Null alleles may also explain the 220 significant deviation from Hardy-Weinberg expectations at these loci (Eaco_054 and Eaco_001), 221 although inbreeding due to population substructure (Wahlund effect) and natural selection are 222 also possible. Null alleles were potentially implicated in 16 out of 42 locus-population 223 combinations, with an estimated frequency of $<0.2$ (Table 4). Null alleles may cause an 
224 overestimation of genetic differentiation (Chapuis \& Estoup, 2007), but the effect is not

225 considerable when their frequency is lower than 0.2 (Carlsson, 2008). To test the effects of null

226 alleles to our datasets, we conducted pairwise $F_{\text {ST }}$ tests by including or excluding locus

227 Eaco_054 (in which 3 out of 7 locations were deviated from HWE after FDR correction );

228 Removing Eaco_054 did not change the results of pairwise comparisons, therefore all loci were

229 included in further analysis. Individual genotypes for these loci are reported in Supplementary 230 material, Table S1.

231

232

233

234

235

236

237

238

239

240

241

242

243

244

245

246

\subsection{Population structure}

Pairwise $F_{\mathrm{ST}}$ values ranged from 0.127 to $0.359 . F_{\mathrm{ST}}$ were significant between all pairs of samples with $\mathrm{P}<0.001$ (Table 5). The largest genetic differentiation was found between samples from NK and ANS $\left(F_{\mathrm{ST}}=0.359\right)$, while the smallest pairwise difference was found between TD and $\mathrm{PR}$ and between $\mathrm{BM}$ and $\mathrm{BK}\left(F_{\mathrm{ST}}=0.127\right)$.

The Neighbor Joining method based on $D_{\mathrm{A}}$ distance identified three major clusters (Fig. 2). Cluster 1 (NK) was genetically distinct from all other populations. Cluster 2 consists of two populations in Java (TD and PR) and two populations in Sumatra (BK and BM). The highest bootstrap support was found between TD and PR. In contrast, two populations, KJ and ANS showed discordance between genetic and geographic distance (cluster 3).

The $\Delta \mathrm{K}$ test in Structure (Pritchard et al., 2010) indicated the maximum value of $\Delta \mathrm{K}$ at $\mathrm{K}=$ 3 with a secondary peak at $\mathrm{K}=6$ and $\mathrm{K}=7$ (Supplementary material, Fig. S1). At $\mathrm{K}=3$, the Structure analysis mirrors the groupings seen in Neighbor Joining tree, with the same three major clusters (NK; KJ, ANS; and TD, PR, BM, BK) (Fig.2). Isolation-by-distance (IBD) revealed 
247 significant correlation between genetic differentiation and geographic distance across all pairs of

248 samples, with $\mathrm{P}=0.003$ (Supplementary material, Fig. S2). Due to the existence of hierarchical

249 structuring, a partial Mantel test was conducted in which population NK was excluded, given the

250 scale of its genetic and geographic distance from all other sites. A partial Mantel performed on

251 the remaining Java and Natuna Sea locations indicated that IBD is present across these sites

$252(\mathrm{p}=0.03$, Fig. 3$)$

253

254 4. Discussion

255 The present study is the first report of genetic diversity (measured as $H_{\mathrm{O}}, H_{\mathrm{E}}$, and the

256 number of alleles), genetic differentiation and phylogeographic patterns of $E$. acoroides in the

257 Indo-Malay Archipelago. Despite the limited number of loci (six microsatellites) used in this

258 study, high observed heterozygosity $\left(H_{\mathrm{O}}\right)$ is found in all populations. Our results are consistent

259 with the general patterns of limited dispersal and restricted gene flow at various geographical

260 scales suggested by previous studies (Lacap et al., 2002; Nakajima et al., 2014). However, our

261 results add to previous studies by not only confirming population differentiation between the

262 Indian and Pacific Ocean but also, reveals surprising and previously unknown structure across

263 the Java and the Natuna Sea.

2654.1 Genetic diversity

266 Genetic diversity is closely related to survivorship, resistance, and resilience of any

267 individual or population to disturbance (Williams, 2001;Hughes \& Stachowicz, 2004). Low

268 genetic diversity can reduce the fitness of individuals, and lead to population extinction

269 (Spielman, Brook \& Frankham, 2004). In recent years, genetic diversity plays a central role in 
270 predicting the ability of individuals or populations to survive environmental change (Hughes \&

271 Stachowicz, 2004), and global climate change (Ehlers, Worm \& Reusch, 2008).

272 Our study revealed that the highest genetic diversity was observed in the central part of

273 Indonesia (BK and PR), while the northernmost population (ANS) possessed lower observed

274 heterozygosity. Sample collection at BK and PR was conducted in undisturbed area where the

275 seagrasses growth in a dense and continues bed (Pers. comm. Putra and Madduppa). Seagrasses

276 in undisturbed area tends to be more genetically diverse (Larkin et al., 2006). Although ANS

277 showed the lowest observed heterozygosity, this may not related to their local environment

278 because sampling location was also conducted in undisturbed area. Microchecker results

279 indicated that ANS had an excess of homozygosity, a potential indicator of inbreeding..

280 Inbreeding mostly occurs in clonal organisms and reduces diversity by reducing the effective

281 frequency of recombination throughout the genome (Charlesworth, 2003).

282 Previous studies of E. acoroides in Lembongan (Bali) and Waigeo (Papua), found that

283 observed heterozygosities were $0.436-0.582$, respectively (Pharmawati et al., 2015). Likewise,

284 using nine microsatellite loci, Nakajima et al. (2014) found observed heterozygosities of $E$.

285 acoroides ranging from $0.165-0.575$ at three locations (Japan, China, and Philippines).

286 Observed heterozygosities of E. acoroides varied from 0.100 to 0.567 in China (Gao et al.,

287 2012), highlighting that our observed values are quite similar to those reported from other sites.

288 The differences in reported heterozygosity ranges between studies could arise due to various

289 factors such as natural selection, variation in the mutational rate, and the number and nature of

290 the loci used.

291 Seagrasses in the Indo-Malay Archipelago, as in other parts in the world, remain subject to

292 overexploitation with conservation efforts largely marginalized. Although the potential decrease 
293 of genetic diversity in seagrasses is quite high due to meadow fragmentation (Vermaat et al.,

294 2004) and extensive clonal growth (Procaccini, Olsen \& Reusch, 2007), E. acoroides appears to

295 retain considerable genetic variation through sexual reproduction. Sexual reproduction

296 contributes significantly to maintaining genetic variation in clonal organisms (Rollon, Cayabyab

$297 \&$ Fortes, 2001). The available life history information also suggests that most seagrass species

298 are predominantly outcrossing (Reusch, 2001).

299

$300 \quad 4.2$ Population genetic structure

301 Pairwise $F_{\mathrm{ST}}$ showed significant genetic differentiation between all pairs of populations.

302 Moreover, Isolation-by-distance (IBD) showed a significant correlation between genetic

303 differentiation and geographic distance, even when the most distant and differentiated population

304 (NK) is excluded. These results indicate that there is low gene flow between populations,

305 possibly due to limited dispersal potential of E. acoroides. For example, Lacap et al. (2002)

306 showed that pollen dispersal of E. acoroides is limited over a small spatial scale, usually less

307 than $10 \mathrm{~km}$. The low gene flow discovered in the present study and from previous studies (e.g.,

308 Nakajima et al., 2014) are consistent with direct observations made on fruit and seed floating

309 time, where median flotation periods were 7 days for fruit and 0.5 hours for seeds, during which

310 time they can cover distances of $41 \mathrm{~km}$ and $0.1 \mathrm{~km}$, respectively (Lacap et al., 2002). After

311 buoyancy is lost for seeds, further seed dispersal probably continues for 2 to 5 days, but the

312 maximum distance was only $204 \mathrm{~cm}$ (Lacap et al., 2002).

313 Limited dispersal distances are also indicated in other seagrass species such as Thalassia

314 hemprichii (Lacap et al., 2002) and Thalassia testudinum (Davis, Childers \& Kuhn, 1999).

315 Likewise, Hosokawa et al. (2015) found that seeds of Zostera marina do not disperse far from 
316 the parent bed. Thus, such local genetic differentiation may be common among seagrass species,

317 although Zostera noltii shows a large geographic area of apparent genetic homogeneity (Coyer et 318 al., 2004).

319 Phylogeographic relationships among E. acoroides suggest its partitioning into three major 320 groups, consistent with Bayesian clustering analysis (Fig. 2). Clustering output indicated

321 secondary peaks at $\mathrm{K}=6$ and $\mathrm{K}=7$. These results indicate the presence of further substructure 322 similar to that found in $F_{\mathrm{ST}}$ analysis. At $\mathrm{K}=6$, all populations are separated except for

323 populations in TD and $\mathrm{PR}$, while at $\mathrm{K}=7$, all populations seem to be genetically distinct. NK,

324 the most geographically distant population, showed distinct genetic structure from the six other

325 sites, and represents the western Indonesian population (Indian Ocean population).

326 Differentiation of the western Indonesian (Indian population) is common in other organisms and 327 is believed to be largely a result of Pleistocene vicariance (Barber et al., 2000; Crandall et al., 328 2008; Yasuda et al., 2009). Low sea level during the Pleistocene would result in the emergence 329 of the Sunda Shelf, which presumably isolates E. acoroides by preventing dispersal. Studies on 330 marine plants such as mangroves, Bruguiera gymnorrhiza (Urashi et al., 2013), genus Ceriops

331 (Huang et al., 2008), and the seagrass H. ovalis (Nguyen et al., 2014) all showed the Sunda Shelf 332 as being a geographical barrier between the Indian and Pacific Ocean populations. Further, 333 similar genetic patterns consistent with Pleistocene isolation have also been reported for marine 334 animals such as in false clownfish Amphiprion ocellaris (Nelson et al., 2000), mantis shrimp 335 Haptosquilla pulchella (Barber et al., 2002), the coral reef fish Caesio cuning (Ackiss et al., 336 2013), the giant clam Tridacna crocea (DeBoer et al., 2014), and five commercially important 337 pelagic fishes (Auxis thazard, Euthynnus affinis, Katsuwonus pelamis, Rastrelliger kanagurta, 338 and Scomberomorus commerson) (Jackson et al., 2014) respectively. 
The geographical partitioning of genetic groups observed in the present study may be a

340 result of various events in the past, but the effect of recent physical oceanography cannot be

341 ignored (DeBoer et al., 2014). The importance of currents in shaping the genetic structure have

342 been reported on both large and small geographical scales (Barber et al., 2002; Galarza et al.,

343 2009; Yasuda et al., 2009; Zhan et al., 2009; Wee et al., 2014). In this region, the South Java

344 Current (SJC) is a unidirectional current, flowing down the west coast of Sumatra (Fig. 1). This

345 current probably acts as a barrier to the dispersal of E. acoroides between NK and the other sites.

346 The genetic structuring of cluster 2 in this study mirrors the genetic structure found in the

347 genus Hippocampus (Lourie, Green \& Vincent, 2005) and Nerita albicilla (Crandall et al., 2008)

348 respectively. However, no phylogeographic break was found across Java Sea, which is in

349 contrast to previous studies carried out in stomatopods (Barber et al., 2002; Barber et al., 2006).

350 It is possible that E. acoroides found appropriate habitat across the Seribu, Bangka, and Batam

351 Islands and used these islands as stepping stones for long distance dispersal. Alternatively,

352 chance may play a role such that each species responds to history in a slight different manner,

353 resulting in a variety of genetic patterns (Bowen et al., 2016). If this were the case, we would

354 expect a shared pattern of genetic structure to emerge if enough species were sampled, as has

355 been reported recently in Hawaii (Toonen et al., 2011; Selkoe et al., 2014, 2016).

356 The alternating monsoon in Indonesia also likely plays an important role in driving

357 dispersal in the region, and is a possible confounding factor for estimating gene flow. Alternating

358 monsoons generate two Seasonally Reversing Currents (SRC) across the Java, Natuna, and South

359 China Seas (Fig. 1). These large storms and reversing currents could also create a complexity of

360 local oceanographic features. Although, previous research did not find evidence of any

361 relationship between genetic patterns and seasonal currents in the Sunda Shelf region for 
362 clownfish (Nelson et al., 2000), our results presented here indicates that SRC may play an

363 important role in the dispersal of E. acoroides.

364 Finally, although we found significant isolation-by-distance overall, two sites (KJ and

365 ANS) showed high genetic similarity despite being geographically distant from one another. This

366 genetic pattern may also have been influenced by sea level changes during the Pleistocene. When

367 the sea level was at $30 \mathrm{~m}$ Below Present Level (BPL), land bridges connecting Sumatra and

368 Borneo via Bangka Belitung seem to have been lost (Voris, 2000). Thus, both the Java and

369 Natuna Seas became connected and this connection may have facilitated gene flow between

370 ANS and KJ. At more recent timescales, oceanographic processes such as SRC may also create

371 and maintain genetic structure between KJ and ANS. Seagrass populations in the Natuna Sea

372 could be originating from a different source.. Kool et al. (2011) suggest that areas in the Natuna

373 Sea are supplied by larval transport from the South China Sea. Other studies showed that

374 populations in the Natuna Sea may also receive propagules from the Andaman Sea via the

375 Malaka Strait following the ice retreat after LGM (Timm \& Kochzius, 2008; Wee et al., 2014).

376 Due to observed differentiation between populations in BM and ANS, we suspect these

377 populations might originate from different areas. The existence of biophysical barriers separating

378 western and eastern part of the Natuna Sea might also responsible for the population

379 differentiation in this area (Treml et al., 2015). However, in order to better understand the origins

380 of the populations in BM and ANS, additional sampling sites from the Malaka Strait and the

381 South China Sea are necessary.

382

3834.3 Implications for restoration and management 

ecosystems (Hemminga \& Duarte, 2000). However, they are declining globally due to human activity and climate change (Duarte, 2002); (Waycott et al., 2009). Restoration of seagrass beds is underway in many sites worldwide (van Katwijk et al., 1998);(Park \& Lee, 2010). Recently, it has been found that genetic diversity plays an important role for seagrass resilience and restoration (Ehlers, Worm \& Reusch, 2008); (Reynolds, McGlathery \& Waycott, 2012).

Here we show there is limited connectivity and significant genetic differentiation between

391 all sampling sites. This study also revealed there are 3 different cluster based on genetic distance

392 and Bayesian clustering. Therefore, we recommend resource managers treat populations across

393 our sampling region as three Management Units (MUs) to maintain the unique genetic

394 characteristics of each region to support seagrass conservation goals. Any restoration activities

395 conducted using local stocks (the same structure cluster) would be beneficial because their

396 genetic diversities have been assessed. Population with higher genetic diversity increases the

397 fitness and reproductive success of the transplants (Williams, 2001). Genetic diversity also

398 contributed to the resistance of seagrass beds to various disturbances (Hughes \& Stachowicz,

399 2004); thus, high diversity creates more resilient ecosystems, and provides more ecosystem

400 services (Reynolds, McGlathery \& Waycott, 2012).

401 Introducing new genotypes through the transplanting seed or plants to other sites should be 402 avoided. Introduction of new alleles that are distinct from native populations would lead to 403 lower survivorship if not locally adapted (Williams, 2001). When migrants are translocated or 404 transferred from one population to another, they may mate with native population and produce 405 offspring that are less fit (outbreeding depression). Although, this has not been documented or 
406 recorded in seagrasses so far, this event has been found in wild populations of scarlet gilia

407 (Ipomopsis aggregata) (Waser, Price \& Shaw, 2000).

408

409

410

\section{Conclusions}

411 Despite the loss of seagrass habitat, these plants manage to maintain good genetic diversity

412 and heterozygosity. Genetic diversity analysis revealed high levels of heterozygosity in all

413 sampling sites. Our results also indicate low gene flow among sites of E. acoroides, as evidenced

414 by significant genetic differentiation among sites, and significant isolation-by-distance. Strong

415 genetic differences were observed between the Indian Ocean population (NK) and all six others.

416 These differences probably represent Pleistocene vicariance between Indian and Pacific

417 populations, consistent with similar patterns in other marine flora and fauna. Seasonally variable

418 currents and extreme storm events may play a role in long-distance dispersal of E. acoroides

419 because the phylogeographic pattern connecting the two peripheral locations that are outliers

420 from the IBD pattern match these alternating currents instead. Our data will help to guide

421 management and restoration efforts by confirming high heterozygosity among most local

422 populations, and highlighting boundaries between which translocations are most desirable. In

423 conclusion, when planning a restoration project, genetically guided criteria should be used in the

424 selection of donor material. Therefore, management plans for seagrass in Indonesia should add

425 such genetic evaluation of seagrasses to conservation and restoration planning.

426

427 Acknowledgments 
We thank Dondy Arafat (Marine Biodiversity and Biosystematics Laboratory, IPB) for

collecting samples in Batam, Ibu Widiastuti (Diponegoro University) for collecting samples in

430 Karimun Jawa, Khalidin for sample collection in Aceh, Dedi, Gugun and Okto for their

431 assistance with sample collection in Bangka. We would like to also express our gratitude

to Indonesian Biodiversity Research Center (IBRC) who had facilitated all the research works,

provided research networks, organized sampling collection and provided laboratory tools and

equipments. This specifically goes to Aji Wahyu Anggoro, Dita Cahyani and Prof. IGN

Mahardika for their contribution in assuring the research running well. We would like to also

thank Samsul Bahri, Astria Yusmalinda, Rizki Wulandari, Andrianus Sembiring, Masriana, Eka

Maya Kurniasih, Dian Pertiwi and Angka Mahardini from IBRC for their help in both the

laboratory and field work.

\section{References}

441

442

443

444

445

446

447

448

449

450

451

452

453

454 455

Ackiss AS, Pardede S, Crandall ED, Ablan-Lagman MCA, Ambariyanto, Romena N, Barber PH, Carpenter KE. 2013. Pronounced genetic structure in a highly mobile coral reef fish, Caesio cuning, in the Coral Triangle. Marine Ecology Progress Series 480:185-197. DOI: $10.3354 /$ meps 10199 .

Allcock AL., Strugnell JM. 2012. Southern Ocean diversity: New paradigms from molecular ecology. Trends in Ecology and Evolution 27:520-528. DOI: 10.1016/j.tree.2012.05.009.

Arnaud-Haond S, Bonhomme F, Borsa P. 1999. Mitochondrial DNA analysis of the genetic relationships among populations of scad mackerel (Decapterus macarellus, D. macrosoma, and D. russelli) in South-East Asia. Marine Biology 135:699-707.

Arriesgado DM., Kurokochi H., Nakajima Y., Matsuki Y., Uy WH., Fortes MD., Campos WL., Nadaoka K., Lian CL. 2015. Genetic diversity and structure of the tropical seagrass Cymodocea serrulata spanning its central diversity hotspot and range edge. Aquatic Ecology. DOI: doi:10.1007/s10452-015-9529-0.

Barber PH, Palumbi SR, Erdmann M V, Moosa MK. 2000. Biogeography: A marine Wallace's line? Nature 406:692-693. DOI: 10.1038/35021135. 
456

457

458

459

460

461

462

463

464

465

466

467

468

469

470

471

472

473

474

475

476

477

478

479

480

481

482

483

484

485

486

487

488

489

490

491

Barber PH, Palumbi SR, Erdmann M V., Moosa MK. 2002. Sharp genetic breaks among populations of Haptosquilla pulchella (Stomatopoda) indicate limits to larval transport: Patterns, causes, and consequences. Molecular Ecology 11:659-674. DOI: 10.1046/j.1365294X.2002.01468.x.

Barber PH, Erdmann M V, Palumbi SR. 2006. Comparative phylogeography of three codistributed stomatopods: origins and timing of regional lineage diversification in the Coral Triangle. Evolution 60:1825-1839. DOI: 10.1111/j.0014-3820.2006.tb00526.x.

Bay LK, Crozier RH, Caley MJ. 2006. The relationship between population genetic structure and pelagic larval duration in coral reef fishes on the Great Barrier Reef. Marine Biology 149:1247-1256. DOI: 10.1007/s00227-006-0276-6.

Benjamini Y, Hochberg Y. 1995. Controlling the false discovery rate: a practical and powerful approach to multiple testing. Journal of the Royal Statistical Society B 57:289-300. DOI: $10.2307 / 2346101$.

Bowen BW, Gaither MR, DiBattista JD, Iacchei M, Andrews KR, Grant WS, Toonen RJ, Briggs JC. 2016. Comparative phylogeography of the ocean planet. Proceedings of the National Academy of Sciences of the United States of America 113:201602404. DOI: 10.1073/pnas.1602404113.

Carlsson J. 2008. Effects of microsatellite null alleles on assignment testing. Journal of Heredity 99:616-623. DOI: 10.1093/jhered/esn048.

Carpenter KE, Barber PH, Crandall ED, Ablan-Lagman MCA, Mahardika GN, ManjajiMatsumoto BM, Juinio-Meñez MA, Santos MD, Starger CJ, Toha AHA. 2011. Comparative Phylogeography of the Coral Triangle and Implications for Marine Management. Journal of Marine Biology 2011:1-14. DOI: 10.1155/2011/396982.

Chapuis MP, Estoup A. 2007. Microsatellite null alleles and estimation of population differentiation. Molecular Biology and Evolution 24:621-631. DOI: 10.1093/molbev/ms1191.

Coyer JA, Diekmann OE, Serrão EA, Procaccini G, Milchakova N, Pearson GA, Stam WT, Olsen JL. 2004. Population genetics of dwarf eelgrass Zostera noltii throughout its biogeographic range. Marine Ecology Progress Series 281:51-62. DOI: $10.3354 /$ meps 281051.

Crandall ED, Frey MA, Grosberg RK, Barber PH. 2008. Contrasting demographic history and phylogeographical patterns in two Indo-Pacific gastropods. Molecular Ecology 17:611-626. DOI: 10.1111/j.1365-294X.2007.03600.x.

Davis J, Childers D, Kuhn D. 1999. Clonal variation in a Florida Bay Thalassia testudinum meadow:molecular genetic assessment of population structure. Marine Ecology Progress Series. DOI: $10.3354 / \mathrm{meps} 186127$. 
492

493

494

495

496

497

498

499

500

501

502

503

504

505

506

507

508

509

510

511

512

513

514

515

516

517

518

519

520

521

522

523

524

525

526

DeBoer TS, Subia MD, Ambariyanto, Erdmann M V, Kovitvongsa K, Barber PH. 2008. Phylogeography and limited genetic connectivity in the endangered boring giant clam across the coral triangle. Conservation Biology 22:1255-1266. DOI: 10.1111/j.15231739.2008.00983.x.

DeBoer TS, Naguit MRA, Erdmann M V, Ablan-Lagman MCA, Carpenter KE, Toha AHA, Barber PH. 2014. Concordant phylogenetic patterns inferred from mitochondrial and microsatellite DNA in the giant clam Tridacna crocea. Bulletin of Marine Science 90:301329. DOI: $10.5343 / \mathrm{bms} .2013 .1002$.

Dempster AP, Laird NM, Rubin DB. 1977. Maximum likelihood from incomplete data via the EM algorithm. Journal of the Royal Statistical Society Series B Methodological 39:1-38. DOI: http://dx.doi.org/10.2307/2984875.

DiBattista JD, Rocha LA, Craig MT, Feldheim KA, Bowen BW. 2012. Phylogeography of two closely related Indo-Pacific butterflyfishes reveals divergent evolutionary histories and discordant results from mtDNA and microsatellites. The Journal of Heredity 103:617-629. DOI: $10.1093 /$ jhered/ess056.

Duarte CM. 2002. The future of seagrass meadows. Environmental Conservation 29:192-206.

Earl DA, VonHoldt BM. 2012. STRUCTURE HARVESTER: A website and program for visualizing STRUCTURE output and implementing the Evanno method. Conservation Genetics Resources 4:359-361. DOI: 10.1007/s12686-011-9548-7.

Ehlers A, Worm B, Reusch T. 2008. Importance of genetic diversity in eelgrass Zostera marina for its resilience to global warming. Marine Ecology Progress Series 355:1-7. DOI: $10.3354 /$ meps 07369 .

Evanno G, Regnaut S, Goudet J. 2005. Detecting the number of clusters of individuals using the software STRUCTURE: A simulation study. Molecular Ecology 14:2611-2620. DOI: 10.1111/j.1365-294X.2005.02553.x.

Excoffier L, Lischer HEL. 2010. Arlequin suite ver 3.5: A new series of programs to perform population genetics analyses under Linux and Windows. Molecular Ecology Resources 10:564-567. DOI: 10.1111/j.1755-0998.2010.02847.x.

Falush D, Stephens M, Pritchard JK. 2003. Inference of population structure using multilocus genotype data: Linked loci and correlated allele frequencies. Genetics 164:1567-1587. DOI: 10.1111/j.1471-8286.2007.01758.x.

Galarza JA, Carreras-Carbonell J, Macpherson E, Pascual M, Roques S, Turner GF, Rico C. 2009. The influence of oceanographic fronts and early-life-history traits on connectivity among littoral fish species. Proceedings of the National Academy of Sciences of the United States of America 106:1473-1478. DOI: 10.1073/pnas.0806804106. 
527

528

529

530

531

532

533

534

535

536

537

538

539

540

541

542

543

544

545

546

547

548

549

550

551

552

553

554

555

556

557

558

559

560
Gao H, Jiang K, Geng Y, Chen X-Y. 2012. Development of microsatellite primers of the largest seagrass, Enhalus acoroides (Hydrocharitaceae). American Journal of Botany 99:e99-e101.

Hart MW, Marko PB. 2010. It's about time: Divergence, demography, and the evolution of developmental modes in marine invertebrates. Integrative and Comparative Biology 50:643-661. DOI: 10.1093/icb/icq068.

Hemminga MA, Duarte CM. 2000. Seagrass Ecology. Cambridge: Cambridge University Press.

Hosokawa S, Nakaoka M, Miyoshi E, Kuwae T. 2015. Seed dispersal in the seagrass Zostera marina is mostly within the parent bed in a protected bay. Marine Ecology Progress Series 523:41-56. DOI: 10.3354/meps 11146 .

Huang Y, Tan F, Su G, Deng S, He H, Shi S. 2008. Population genetic structure of three tree species in the mangrove genus Ceriops (Rhizophoraceae) from the Indo West Pacific. Genetica 133:47-56. DOI: 10.1007/s10709-007-9182-1.

Hughes AR, Stachowicz JJ. 2004. Genetic diversity enhances the resistance of a seagrass ecosystem to disturbance. Proceedings of the National Academy of Sciences of the United States of America 101:8998-9002. DOI: 10.1073/pnas.0402642101.

Jackson AM, Erdmann M V, Toha AHA, Stevens LA, Barber PH. 2014. Phylogeography of commercial tuna and mackerel in the Indonesian Archipelago. Bulletin of Marine Science 90:471-492. DOI: 10.5343/bms.2012.1097.

Jakobsson M, Rosenberg NA. 2007. CLUMPP: A cluster matching and permutation program for dealing with label switching and multimodality in analysis of population structure. Bioinformatics 23:1801-1806. DOI: 10.1093/bioinformatics/btm233.

Jennings S, Blanchard JL. 2004. Fish abundance with no fishing: Predictions based on macroecological theory. Journal of Animal Ecology 73:632-642. DOI: 10.1111/j.00218790.2004.00839.x.

Jensen JL, Bohonak AJ, Kelley ST. 2005. Isolation by distance, web service. BMC genetics 6:13. DOI: $10.1186 / 1471-2156-6-13$.

Van Katwijk MM, Schmitz GH, Hanssen LSAM, den Hartog C. 1998. Suitability of Zostera marina populations for transplantation to the Wadden Sea as determined by a mesocosm shading experiment. Aquatic Botany 60:283-305. DOI: 10.1016/S0304-3770(98)00053-9.

Kearse M, Moir R, Wilson A, Stones-Havas S, Cheung M, Sturrock S, Buxton S, Cooper A, Markowitz S, Duran C, Thierer T, Ashton B, Meintjes P, Drummond A. 2012. Geneious Basic: An integrated and extendable desktop software platform for the organization and analysis of sequence data. Bioinformatics 28:1647-1649. DOI: 10.1093/bioinformatics/bts 199 . 
561 Kendall MS, Battista T, Hillis-Starr Z. 2004. Long term expansion of a deep Syringodium

562

563

564

565

566

567

568

569

570

571

572

573

574

575

576

577

578

579

580

581

582

583

584

585

586

587

588

589

590

591

592

593

594 filiforme meadow in St. Croix, US Virgin Islands: The potential role of hurricanes in the dispersal of seeds. Aquatic Botany 78:15-25. DOI: 10.1016/j.aquabot.2003.09.004.

Keyse J, Crandall ED, Toonen RJ, Meyer CP, Treml EA, Riginos C. 2014. The scope of published population genetic data for Indo-Pacific. Bulletin of Marine Science 90:1-32. DOI: $10.5343 / \mathrm{bms} .2012 .1107$.

Kiswara W, Hutomo M. 1985. Habitat dan sebaran geografik lamun. Oseana 10:21-30.

Kool JT, Paris CB, Barber PH, Cowen RK. 2011. Connectivity and the development of population genetic structure in Indo-West Pacific coral reef communities. Global Ecology and Biogeography 20:695-706. DOI: 10.1111/j.1466-8238.2010.00637.x.

Lacap CDA, Vermaat JE, Rollon RN, Nacorda HM. 2002. Propagule dispersal of the SE Asian seagrasses Enhalus acoroides and Thalassia hemprichii. Marine Ecology Progress Series 235:75-80.

Liao PC, Havanond S, Huang S. 2006. Phylogeography of Ceriops tagal (Rhizophoraceae) in Southeast Asia: the land barrier of the Malay Peninsula has caused population differentiation between the Indian Ocean and South China Sea. Conservation Genetics 8:89-98. DOI: 10.1007/s10592-006-9151-8.

Lourie SA, Green DM, Vincent ACJ. 2005. Dispersal, habitat differences, and comparative phylogeography of Southeast Asian seahorses (Syngnathidae: Hippocampus). Molecular Ecology 14:1073-1094. DOI: 10.1111/j.1365-294X.2005.02464.x.

Madduppa HH, Timm J, Kochzius M. 2014. Interspecific, spatial and temporal variability of self-recruitment in anemonefishes. PloS one 9:e90648. DOI: 10.1371/journal.pone.0090648.

Meirmans PG. 2012. The trouble with isolation by distance. Molecular Ecology 21:2839-2846.

Nakajima Y, Matsuki Y, Lian C, Fortes MD, Uy WH, Campos WL, Nakaoka M, Nadaoka K. 2012. Development of novel microsatellite markers in a tropical seagrass, Enhalus acoroides. Conservation Genetics Resources 4:515-517. DOI: 10.1007/s12686-012-9614-9.

Nakajima Y, Matsuki Y, Lian C, Fortes MD, Uy WH, Campos WL, Nakaoka M, Nadaoka K. 2014. The Kuroshio current influences genetic diversity and population genetic structure of a tropical seagrass, Enhalus acoroides. Molecular Ecology 23:6029-6044. DOI: 10.1111/mec.12996.

Nei M, Tajima F, Tateno Y. 1983. Accuracy of estimated phylogenetic trees from molecular data - II. Gene frequency data. Journal of Molecular Evolution 19:153-170. DOI: 10.1007/BF02300753. 
595 Nelson JS, Hoddell RJ, Chou LM, Chan WK, Phang VPE. 2000. Phylogeographic structure of 596 false clownfish, Amphiprion ocellaris, explained by sea level changes on the Sunda shelf. 597 Marine Biology 137:727-736. DOI: 10.1007/s002270000379.

598

599

600

601

602

603

604

605

606

607

608

609

610

611

612

613

614

615

616

617

618

619

620

621

622

623

624

625

626

627

628

629

630

Nguyen VX, Detcharoen M, Tuntiprapas P, Sidik JB, Harah MZ. 2014. Genetic species identification and population structure of Halophila ( Hydrocharitaceae ) from the Western Pacific to the Eastern Indian Ocean. BMC Evolutionary Biology 14:1-18. DOI: $10.1186 / 1471-2148-14-92$.

Van Oosterhout C, Hutchinson WF, Wills DPM, Shipley P. 2004. MICROCHECKER: Software for identifying and correcting genotyping errors in microsatellite data. Molecular Ecology Notes 4:535-538. DOI: 10.1111/j.1471-8286.2004.00684.x.

Park JI, Lee KS. 2010. Development of transplantation method for the restoration of surfgrass, Phyllospadix japonicus, in an exposed rocky shore using an artificial underwater structure. Ecological Engineering 36:450-456. DOI: 10.1016/j.ecoleng.2009.11.012.

Peakall R, Smouse PE. 2012. GenALEx 6.5: Genetic analysis in Excel. Population genetic software for teaching and research-an update. Bioinformatics 28:2537-2539. DOI: 10.1093/bioinformatics/bts460.

Pharmawati M, Putra ING, Syamsuni YF, Mahardika IGNK. 2015. Genetic diversity of Enhalus acoroides (L.) Royle from coastal waters of Pramuka Island, Lembongan Island, and Waigeo Island, Indonesia, based on microsatellite DNA. Advanced Science Letters 21:199202. DOI: $10.1166 /$ asl.2015.5861.

Poortvliet M, Longo GC, Selkoe K, Barber PH, White C, Caselle JE, Perez-Matus A, Gaines SD, Bernardi G. 2013. Phylogeography of the California sheephead, Semicossyphus pulcher: the role of deep reefs as stepping stones and pathways to antitropicality. Ecology and Evolution 3:4558-4571. DOI: 10.1002/ece3.840.

Pritchard JK, Stephens M, Donnelly P. 2000. Inference of population structure using multilocus genotype data. Genetics 155:945-959. DOI: 10.1111/j.1471-8286.2007.01758.x.

Procaccini G., Olsen JL., Reusch TBH. 2007. Contribution of genetics and genomics to seagrass biology and conservation. Journal of Experimental Marine Biology and Ecology 350:234259. DOI: $10.1016 /$ j.jembe.2007.05.035.

Reusch TBH. 2001. New markers - Old questions: Population genetics of seagrasses. Marine Ecology Progress Series 211:261-274. DOI: 10.3354/meps211261.

Reynolds LK, McGlathery KJ, Waycott M. 2012. Genetic diversity enhances restoration success by augmenting ecosystem services. PloS one 7:e38397. DOI: 10.1371/journal.pone.0038397.

Riani E, Djuwita I, Budiharsono S, Purbayanto A, Asmus H. 2012. Challenging for seagrass management in Indonesia. Journal of Coastal Development 15:234-242. 
631 Rollon RN., Cayabyab NM., Fortes MD. 2001. Vegetative dynamics and sexual reproduction of 632 monospecific Thalassia hemprichii meadows in the Kalayaan Island Group. Aquatic Botany 633 71:239-246. DOI: 10.1016/S0304-3770(01)00178-4.

634 Rosenberg NA. 2004. DISTRUCT: A program for the graphical display of population structure. Molecular Ecology Notes 4:137-138. DOI: 10.1046/j.1471-8286.2003.00566.x.

636

637

638

639

640

641

642

643

644

645

646

647

648

649

650

651

652

653

654

655

656

657

658

659

660

661

662

663

664

665

Saitou N, Nei M. 1987. The neighbor-joining method: a new method for reconstructing phylogenetic trees. Molecular Biology and Evolution 4:406-425. DOI: citeulike-articleid:93683.

Selkoe KA, Gaggiotti OE, Bowen BW, Toonen RJ. 2014. Emergent patterns of population genetic structure for a coral reef community. Molecular Ecology 23:3064-3079. DOI: 10.1111/mec.12804.

Selkoe KA, Gaggiotti OE, Treml E a, Wren JLK, Donovan MK, Toonen RJ. 2016. The DNA of coral reef biodiversity: predicting and protecting genetic diversity of reef assemblages. Proceedings. Biological sciences / The Royal Society 283:20160354-. DOI: 10.1098/rspb.2016.0354.

Selkoe KA, Toonen RJ. 2006. Microsatellites for ecologists: a practical guide to using and evaluating microsatellite markers. Ecology Letters 9:615-29. DOI: 10.1111/j.14610248.2006.00889.x.

Short FT, Waycott M. 2010.Enhalus acoroides. Available at http://www.iucnredlist.org/ (accessed April 15, 2015).

Spielman D, Brook BW, Frankham R. 2004. Most species are not driven to extinction before genetic factors impact them. Proceedings of the National Academy of Sciences of the United States of America 101:15261-4. DOI: 10.1073/pnas.0403809101.

Takezaki N, Nei M, Tamura K. 2010. POPTREE2: Software for constructing population trees from allele frequency data and computing other population statistics with windows interface. Molecular Biology and Evolution 27:747-752. DOI: 10.1093/molbev/msp312.

Tamura K, Peterson D, Peterson N, Stecher G, Nei M, Kumar S. 2011. MEGA5: Molecular evolutionary genetics analysis using maximum likelihood, evolutionary distance, and maximum parsimony methods. Molecular Biology and Evolution 28:2731-2739. DOI: 10.1093/molbev/msr121.

Thresher RE, Brothers EB. 1985. Reproductive ecology and biogeography of Indo-West Pacific Angelfishes (Pisces: Pomacanthidae). Evolution 39:878-887. DOI: 10.2307/2408687.

Timm J, Kochzius M. 2008. Geological history and oceanography of the Indo-Malay Archipelago shape the genetic population structure in the false clown anemonefish (Amphiprion ocellaris). Molecular Ecology 17:3999-4014. 
666 Toonen RJ, Andrews KR, Baums IB, Bird CE, Concepcion GT, Daly-Engel TS, Eble JA, Faucci 667 A, Gaither MR, Iacchei M, Puritz JB, Schultz JK, Skillings DJ, Timmers MA, Bowen BW. 2011. Defining Boundaries for Ecosystem-Based Management: A Multispecies Case Study of Marine Connectivity across the Hawaiian Archipelago. Journal of Marine Biology 2011:1-13.

672

Treml EA, Roberts J, Halpin PN, Possingham HP, Riginos C. 2015. The emergent geography of biophysical dispersal barriers across the Indo-West Pacific. Diversity and Distributions:1-

673 12.

674

675

676

677

678

679

680

681

682

683

684

685

686

687

688

689

690

691

692

693

694

695

696

697

698

699

700

701

702

Urashi C, Teshima KM, Minobe S, Koizumi O, Inomata N. 2013. Inferences of evolutionary history of a widely distributed mangrove species, Bruguiera gymnorrhiza, in the Indo-West Pacific region. Ecology and Evolution 3:2251-61. DOI: 10.1002/ece3.624.

Vermaat JE., Rollon RN., Lacap CDA., Billot C., Alberto F., Nacorda HME., Wiegman F., Terrados J. 2004. Meadow fragmentation and reproductive output of the SE Asian seagrass Enhalus acoroides. Journal of Sea Research 52:321-328. DOI: 10.1016/j.seares.2004.04.002.

Vogler C, Benzie J, Lessios H, Barber P, Worheide G. 2008. A threat to coral reefs multiplied? Four species of crown-of-thorns starfish. Biology Letters 4:696-699. DOI: 10.1098/rsbl.2008.0454.

Voris HK. 2000. Maps of Pleistocene sea levels in SoutheastAsia: shorelines, river systems and time durations. Journal of Biogeography 27:1153-1167. DOI: 10.1046/j.13652699.2000.00489.x.

Waser NM, Price M V., Shaw RG. 2000. Outbreeding depression varies among cohorts of Ipomopsis aggregata planted in nature. Evolution 54:485-491. DOI: 10.1111/j.00143820.2000.tb00051.x.

Waycott M, Duarte CM, Carruthers TJB, Orth RJ, Dennison WC, Olyarnik S, Calladine A, Fourqurean JW, Heck KL, Hughes AR, Kendrick GA, Kenworthy WJ, Short FT, Williams SL. 2009. Accelerating loss of seagrasses across the globe threatens coastal ecosystems. Proceedings of the National Academy of Sciences of the United States of America 106:12377-12381. DOI: 10.1073/pnas.0905620106

Wee AKS, Takayama K, Asakawa T, Thompson B, Sungkaew S, Tung NX, Nazre M, Soe KK, Tan HTW, Watano Y, Baba S, Kajita T, Webb EL. 2014. Oceanic currents, not land masses, maintain the genetic structure of the mangrove Rhizophora mucronata Lam. (Rhizophoraceae) in Southeast Asia. Journal of Biogeography 41:954-964. DOI: 10.1111/jbi.12263.

Wee AKS, Takayama K, Chua JL, Asakawa T, Meenakshisundaram SH, Adjie B, Ardli ER, Sungkaew S, Malekal NB, Tung NX. 2015. Genetic differentiation and phylogeography of partially sympatric species complex Rhizophora mucronata Lam . and $R$. stylosa Griff . 
703

704

705

706

707

708

709

710

711

712

713

714

715

716

717 using SSR markers. BMC Evolutionary Biology 15:1-13. DOI: 10.1186/s12862-015-03313.

Weir BS, Cockerham CC. 1984. Estimating F-statistics for the analysis of population structure. Evolution 38:1358-1370. DOI: 10.2307/2408641.

Williams SL. 2001. Reduced genetic diversity in eelgrass transplantation affects both population growth and individual fitness. Ecological Applications 11:1472-1488. DOI: 10.1890/10510761(2001)011[1472:RGDIET]2.0.CO;2.

Yasuda N, Nagai S, Hamaguchi M, Okaji K, Gérard K, Nadaoka K. 2009. Gene flow of Acanthaster planci (L.) in relation to ocean currents revealed by microsatellite analysis. Molecular Ecology 18:1574-1590. DOI: 10.1111/J.1365-294x.2009.04133.X.

Zhan A, Hu J, Hu X, Zhou Z, Hui M, Wang S, Peng W, Wang M, Bao Z. 2009. Fine-scale population genetic structure of Zhikong scallop (Chlamys farreri): do local marine currents drive geographical differentiation? Marine Biotechnology 11:223-235. DOI: 10.1007/s10126-008-9138-1. 
718 Figure legends.

719

720

721

722

723

724

725

726

727

728

729

730

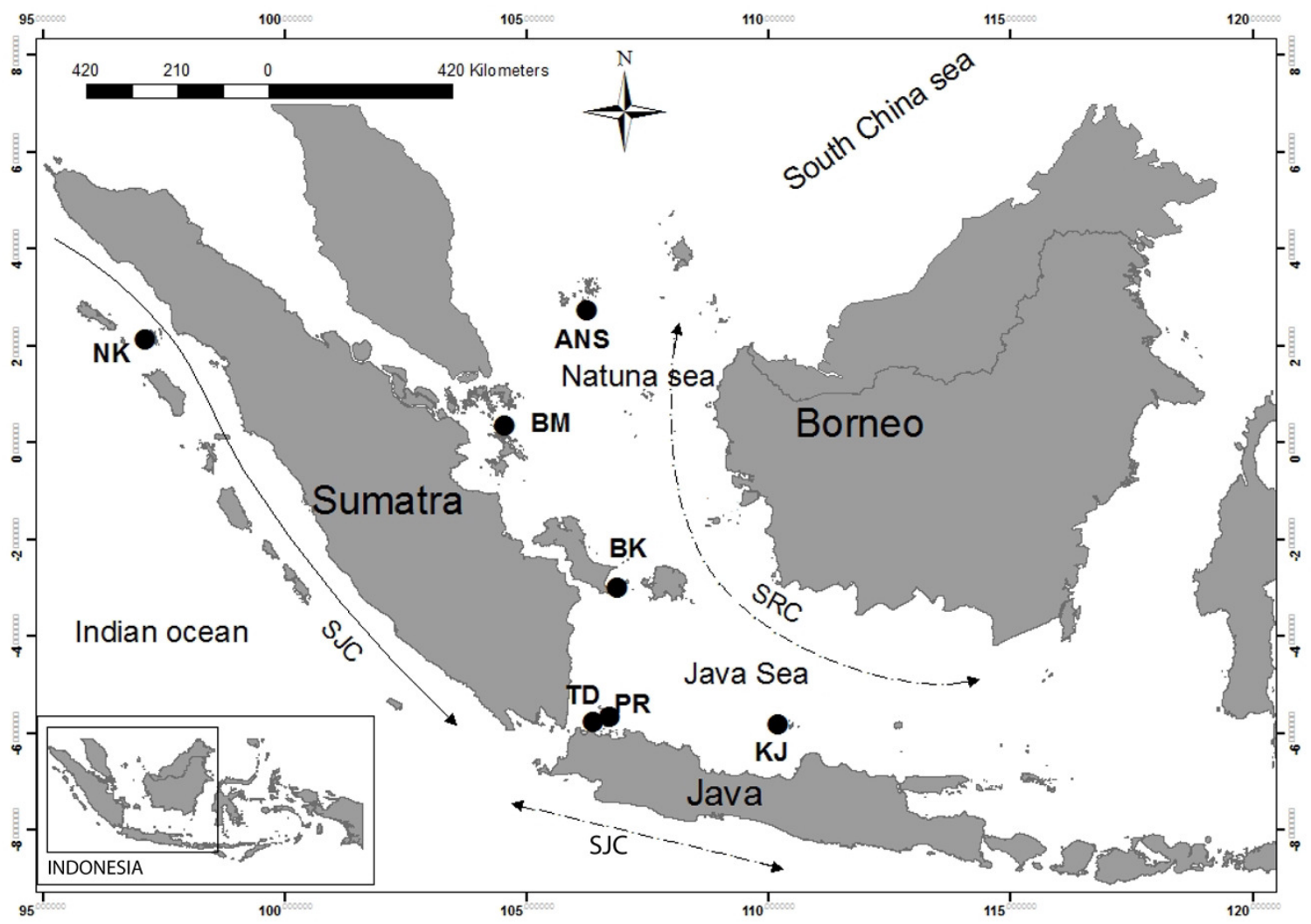

731 Fig.1 Sampling location from which Enhalus acoroides were collected for present study.

732 Sampling sites indicated by black circles. NK: Nakuri, BK: Bangka, BM: Batam, ANS:

733 Anambas, TD: Tunda, PR: Pramuka, KJ: Karimun Jawa, SJC: South Java Current, SRC:

734 Seasonality Reversing Current.

735

736

737

738

739 

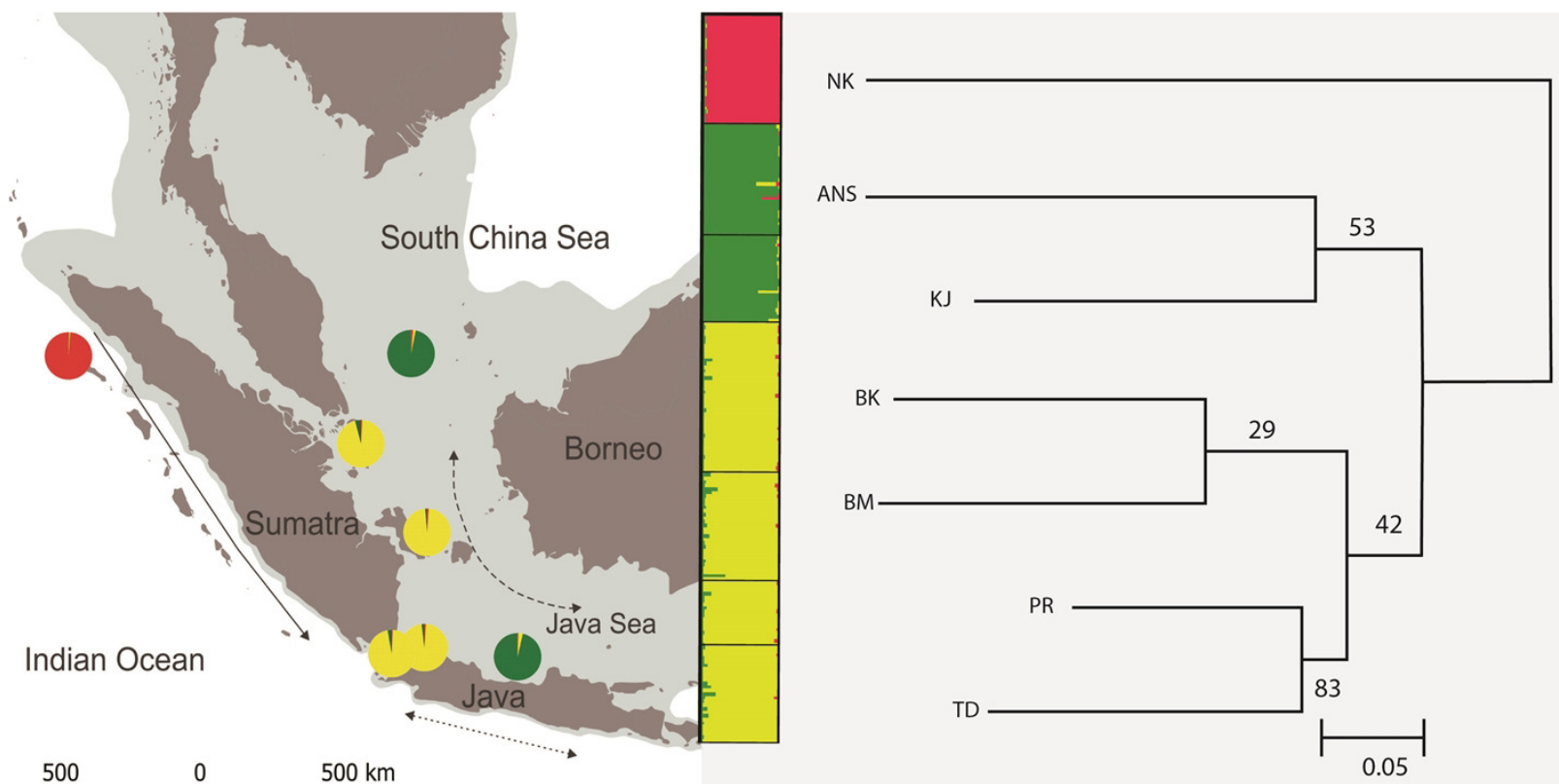

750

751 Fig.2 Neighbor Joining (NJ) tree based on $D_{\mathrm{A}}$ distance is consistent with Structure (clustering inset) showing all populations were divided into three clusters (NK/TD, PR, BK and BM/ANS and KJ). Each color represents one cluster in the Structure analysis and the length of each colored segment shows proportion of coanscestry as a measure of membership in that cluster.

755 Bootstrap values on the NJ tree are shown besides the node as the number replicates, out of 100, 756 in which the cluster was formed. 
757

758

759

760

761

762

763

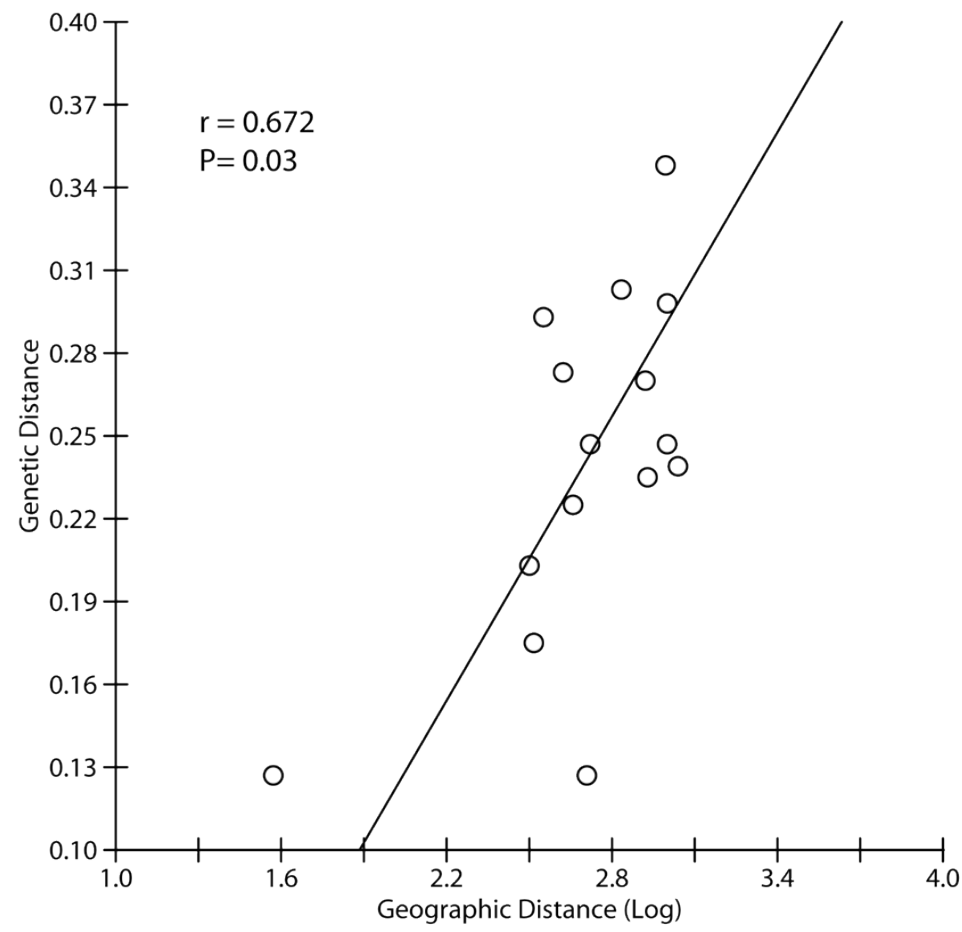

764 Fig. 3 Correlation between genetic and geographic distance used partial Mantel test based on $F_{\text {ST }}$

765 and as genetic distance excluding NK, the most divergent population in all analyses. 


\section{Tables}

767 Table 1 Sampling location, abbreviation, geographical coordinates and the number of samples

768 used in this study

\begin{tabular}{llrrl}
\hline Collection site & Abbreviation & Latitude & Longitude & $\begin{array}{l}\text { Number of } \\
\text { individuals }\end{array}$ \\
\hline Nakuri Island, Aceh & NK & $2.21^{\circ}$ & $97.30^{\circ}$ & 30 \\
Batam, Riau Archipelago & BM & $0.74^{\circ}$ & $104.34^{\circ}$ & 30 \\
Bangka island, Bangka Belitung & BK & $-2.97^{\circ}$ & $106.65^{\circ}$ & 42 \\
Anambas, Riau Archipelago & ANS & $3.11^{\circ}$ & $106.33^{\circ}$ & 31 \\
Pramuka Island, Seribu Islands & PR & $-5.74^{\circ}$ & $106.61^{\circ}$ & 18 \\
Tunda Island, Banten & TD & $-5.81^{\circ}$ & $106.28^{\circ}$ & 27 \\
Karimun Jawa, Jawa Tengah & KJ & $-5.86^{\circ}$ & $110.40^{\circ}$ & 24 \\
Total & & & & 202 \\
\hline
\end{tabular}

769

770

771 Table 2 Eight polymorphic microsatellite loci in E. acoroides: locus name, primer sequence,

772 dye, product size range, repeat motif and GeneBank accession number.

773

\begin{tabular}{|c|c|c|c|c|c|}
\hline Loci & $\begin{array}{l}\text { Primer } \\
\text { sequence (5'- } \\
\left.3^{\prime}\right)\end{array}$ & Dye & Size range (bp) & Repeat motif & Accession no. \\
\hline Eaco_001 & $\begin{array}{l}\text { GGCTTGAGT } \\
\text { TTGTTTAGA } \\
\text { ATTCTAG F } \\
\text { GGTTTTCCC } \\
\text { AGTCACGAC } \\
\text { GTTACATGT } \\
\text { GGAATGCAT } \\
\text { ACAC R }\end{array}$ & FAM & $232-246$ & $(\mathrm{TG})_{16}$ & AB689192 \\
\hline Eaco_009 & $\begin{array}{l}\text { CAATCGTCC } \\
\text { AATCCAAAG } \\
\text { GC F } \\
\text { GGTTTTCCC } \\
\text { AGTCACGAC } \\
\text { GGGAGAATT } \\
\text { GTATTATTTA } \\
\text { C R }\end{array}$ & FAM & $142-154$ & $(\mathrm{TG})_{13}$ & AB689194 \\
\hline Eaco_019 & $\begin{array}{l}\text { AGGTATTCC } \\
\text { TTACCACCG } \\
\text { TTC F } \\
\text { GGTTTTCCC } \\
\text { AGTCACGAC } \\
\text { GCACGGAGG }\end{array}$ & VIC & $195-197$ & $(\mathrm{CT})_{7}$ & AB689197 \\
\hline
\end{tabular}




\begin{tabular}{|c|c|c|c|c|c|}
\hline & $\begin{array}{l}\text { TCTTTCGAA } \\
\text { GTTG R }\end{array}$ & & & & \\
\hline \multirow[t]{8}{*}{ Eaco_050 } & GAATAAATC & NED & $243-255$ & $(\mathrm{TG})_{9} \mathrm{TA}(\mathrm{TG})_{5}$ & AB689199 \\
\hline & AAGTCCCTT & & & TATG(TA $)_{8}$ & \\
\hline & GAG F & & & & \\
\hline & GGTTTTCCC & & & & \\
\hline & AGTCACGAC & & & & \\
\hline & GCAAATAAG & & & & \\
\hline & ATGTGGCTT & & & & \\
\hline & AC R & & & & \\
\hline \multirow[t]{8}{*}{ Eaco_051 } & CATACAGAT & PET & $206-231$ & $(\mathrm{GA})_{15} \mathrm{GTGC}(\mathrm{G}$ & AB689200 \\
\hline & GCATGCATA & & & $\mathrm{T})_{16}$ & \\
\hline & CTC F & & & $\mathrm{GC}(\mathrm{GT})_{4}$ & \\
\hline & GGTTTTCCC & & & & \\
\hline & AGTCACGAC & & & & \\
\hline & GCTAAGCGC & & & & \\
\hline & TACGTGGTA & & & & \\
\hline & CTAG R & & & & \\
\hline \multirow[t]{8}{*}{ Eaco_052 } & CAGGCGCAC & NED & $147-149$ & $(\mathrm{TG})_{4} \mathrm{TC}(\mathrm{TG})_{4}$ & AB689201 \\
\hline & AACGTATGT & & & $\mathrm{TC}(\mathrm{TG})_{5}$ & \\
\hline & $\mathrm{AC} \mathrm{F}$ & & & & \\
\hline & GGTTTTCCC & & & & \\
\hline & AGTCACGAC & & & & \\
\hline & GGAACCACA & & & & \\
\hline & TCATCAGTG & & & & \\
\hline & TG R & & & & \\
\hline \multirow[t]{8}{*}{ Eaco_054 } & GCTTCTAATT & PET & $267-295$ & $(\mathrm{CT})_{15}$ & AB689202 \\
\hline & AGCATTTTG & & & & \\
\hline & GACTTCAG F & & & & \\
\hline & GGTTTTCCC & & & & \\
\hline & AGTCACGAC & & & & \\
\hline & GATTTGGGA & & & & \\
\hline & CGTCCAAAG & & & & \\
\hline & AG R & & & & \\
\hline \multirow[t]{8}{*}{ Eaco_055 } & CTTTTGCTCC & PET & $165-191$ & $(\mathrm{TC})_{18} \mathrm{CG}(\mathrm{TG})_{1}$ & AB689203 \\
\hline & CAAATTGAA & & & 6 & \\
\hline & TG F & & & & \\
\hline & GGTTTTCCC & & & & \\
\hline & AGTCACGAC & & & & \\
\hline & GATGCTTAG & & & & \\
\hline & TGCAGCTTG & & & & \\
\hline & TTC R & & & & \\
\hline
\end{tabular}

774

775 F: forward, R: reverse

776

777 Table 3 Summary of genetic diversity for E. acoroides. Genetic diversity was inferred from the

778 numbers of alleles $(\mathrm{A})$, observed heterozygosities $\left(H_{\mathrm{O}}\right)$ and expected heterozygosities $\left(H_{\mathrm{E}}\right)$.

779 Numbers in bold indicate significant deviation from Hardy-Weinberg equilibrium prior to 
780 multiple test correction and bold number with * (asterix) indicated significant deviation at $\mathrm{P}<$

7810.05 after corrections for false discovery rates (Benjamini \& Hochberg, 1995)

\begin{tabular}{|c|c|c|c|c|c|c|c|c|c|}
\hline \multirow[b]{2}{*}{ Loci } & \multicolumn{7}{|c|}{ Locations } & \multirow{2}{*}{$\begin{array}{l}\text { Total } \\
\text { alleles }\end{array}$} & \multirow{2}{*}{$\begin{array}{l}\text { Mean } \\
\text { A/locus }\end{array}$} \\
\hline & TD & PR & $\mathrm{NK}$ & $\mathrm{BM}$ & $\mathrm{KJ}$ & $\mathrm{BK}$ & ANS & & \\
\hline \multicolumn{10}{|c|}{ Eaco_001 } \\
\hline A & 3 & 2 & 8 & 5 & 2 & 3 & 2 & \multirow[t]{4}{*}{10} & \multirow[t]{4}{*}{3.57} \\
\hline$H_{\mathrm{O}}$ & 0.185 & 0.389 & 0.400 & 0.467 & 0.417 & 0.429 & 0.355 & & \\
\hline$H_{\mathrm{E}}$ & 0.427 & 0.375 & 0.611 & 0.417 & 0.375 & 0.489 & 0.331 & & \\
\hline $\mathrm{P}$ & $0.002 *$ & 1.000 & $0.000 *$ & 0.834 & 1.000 & 0.274 & 1.000 & & \\
\hline \multicolumn{10}{|c|}{ Eaco_009 } \\
\hline A & 5 & 5 & 2 & 6 & 6 & 6 & 6 & \multirow[t]{4}{*}{10} & \multirow[t]{4}{*}{5.14} \\
\hline$H_{\mathrm{O}}$ & 0.667 & 0.667 & 0.033 & 0.600 & 0.417 & 0.786 & 0.613 & & \\
\hline$H_{\mathrm{E}}$ & 0.658 & 0.650 & 0.095 & 0.660 & 0.549 & 0.677 & 0.592 & & \\
\hline $\mathrm{P}$ & 0.940 & 0.952 & 0.049 & 0.331 & 0.017 & 0.674 & 0.026 & & \\
\hline \multicolumn{10}{|c|}{ Eaco_019 } \\
\hline A & 2 & 2 & 3 & 1 & 1 & 1 & 1 & \multirow[t]{5}{*}{3} & \multirow[t]{4}{*}{1.57} \\
\hline$H_{\mathrm{O}}$ & 0.111 & 0.500 & 0.467 & 0.000 & 0.000 & 0.000 & 0.000 & & \\
\hline$H_{\mathrm{E}}$ & 0.105 & 0.461 & 0.376 & 0.000 & 0.000 & 0.000 & 0.000 & & \\
\hline $\mathrm{P}$ & 1.000 & 1.000 & 0.610 & N.A & N.A & N.A & N.A & & \\
\hline \multicolumn{9}{|c|}{ Eaco_051 } & \\
\hline A & 9 & 4 & 9 & 9 & 7 & 10 & 8 & \multirow[t]{5}{*}{19} & \multirow[t]{4}{*}{8.00} \\
\hline$H_{\mathrm{O}}$ & 0.852 & 0.722 & 0.933 & 0.667 & 0.917 & 0.905 & 0.633 & & \\
\hline$H_{\mathrm{E}}$ & 0.811 & 0.619 & 0.808 & 0.757 & 0.759 & 0.826 & 0.724 & & \\
\hline $\mathrm{P}$ & 0.554 & 0.861 & 0.504 & 0.022 & 0.009 & 0.905 & 0.189 & & \\
\hline \multicolumn{9}{|c|}{ Eaco_054 } & \\
\hline A & 10 & 8 & 10 & 13 & 6 & 12 & 8 & \multirow[t]{5}{*}{29} & \multirow[t]{4}{*}{9.57} \\
\hline$H_{\mathrm{O}}$ & 0.630 & 0.667 & 0.800 & 0.833 & 0.792 & 0.810 & 0.290 & & \\
\hline$H_{\mathrm{E}}$ & 0.858 & 0.789 & 0.839 & 0.792 & 0.658 & 0.841 & 0.388 & & \\
\hline $\mathrm{P}$ & $0.000 *$ & 0.171 & 0.003 * & 0.246 & 0.725 & 0.880 & $0.006 *$ & & \\
\hline \multicolumn{9}{|c|}{ Eaco_055 } & \\
\hline A & 6 & 6 & 9 & 8 & 4 & 7 & 5 & \multirow[t]{5}{*}{18} & \multirow[t]{4}{*}{6.43} \\
\hline$H_{\mathrm{O}}$ & 0.704 & 0.667 & 0.700 & 0.800 & 0.667 & 0.762 & 0.710 & & \\
\hline$H_{\mathrm{E}}$ & 0.771 & 0.657 & 0.823 & 0.699 & 0.656 & 0.747 & 0.710 & & \\
\hline $\mathrm{P}$ & 0.130 & 0.427 & 0.075 & 0.889 & 0.143 & 0.090 & 0.022 & & \\
\hline \multicolumn{9}{|c|}{ All pop. } & \\
\hline A & 5.83 & 4.50 & 6.83 & 7.00 & 4.33 & 6.50 & 5.00 & \multirow[t]{3}{*}{14.83} & 5.71 \\
\hline$H_{\mathrm{O}}$ & 0.525 & 0.602 & 0.556 & 0.561 & 0.535 & 0.615 & 0.434 & & 0.547 \\
\hline$H_{\mathrm{E}}$ & 0.605 & 0.592 & 0.592 & 0.554 & 0.499 & 0.597 & 0.458 & & 0.557 \\
\hline
\end{tabular}

782

783 Table 4 Frequency of null alleles per locus per population for E. acoroides

\begin{tabular}{cccccccc}
\hline & \multicolumn{7}{c}{ Population } \\
\cline { 2 - 7 } Loci & TD & PR & NK & BM & KJ & BK & ANS \\
\hline
\end{tabular}




\begin{tabular}{llllllll}
\hline Eaco_009 & 0.000 & 0.000 & 0.110 & 0.043 & 0.077 & 0.000 & 0.008 \\
Eaco_019 & 0.000 & 0.000 & 0.000 & 0.001 & 0.001 & 0.001 & 0.001 \\
Eaco_054 & 0.121 & 0.041 & 0.000 & 0.000 & 0.000 & 0.011 & 0.068 \\
Eaco_001 & 0.174 & 0.000 & 0.145 & 0.000 & 0.000 & 0.038 & 0.000 \\
Eaco_051 & 0.000 & 0.000 & 0.000 & 0.029 & 0.000 & 0.000 & 0.048 \\
Eaco_055 & 0.070 & 0.000 & 0.067 & 0.000 & 0.000 & 0.002 & 0.056 \\
\hline
\end{tabular}

785 Table 5 Pairwise $F_{\text {ST }}$ values (below diagonal) and geographic distances (above diagonal)

\begin{tabular}{llllllll}
\hline & TD & PR & NK & BM & KJ & BK & ANS \\
\hline TD & - & 37.3 & 1,418 & 850 & 456 & 328 & 1,000 \\
PR & $0.127^{*}$ & - & 1,456 & 834 & 419 & 317 & 986 \\
NK & $0.290^{*}$ & $0.302^{*}$ & - & 1,706 & 1,875 & 1,716 & 2,050 \\
BM & $0.235^{*}$ & $0.270^{*}$ & $0.301^{*}$ & - & 1,000 & 511 & 356 \\
KJ & $0.225^{*}$ & $0.273^{*}$ & $0.338^{*}$ & $0.247^{*}$ & - & 525 & 1,095 \\
BK & $0.175^{*}$ & $0.203^{*}$ & $0.214^{*}$ & $0.127^{*}$ & $0.247^{*}$ & - & 682 \\
ANS & $0.298^{*}$ & $0.348^{*}$ & $0.359^{*}$ & $0.293^{*}$ & $0.239^{*}$ & $0.303^{*}$ & - \\
\hline
\end{tabular}

